\title{
The Use of Restriction Fragment Length Polymorphism and Fluorescence in Situ Hybridization to Investigate Microbiota of Piglets after Feeding Oregano
}

\author{
Katrin Stelter ${ }^{1}$, Andreas Berk ${ }^{*}$, Lutz Geue ${ }^{2}$, Stefanie Barth ${ }^{2}$, Petra Schlien ${ }^{3}$, \\ Alexander Swidsinski ${ }^{3}$, Sven Dänicke ${ }^{1}$ \\ ${ }^{1}$ Institute of Animal Nutrition, Friedrich-Loeffler-Institute (FLI), Federal Research Institute for Animal Health, \\ Braunschweig, Germany \\ ${ }^{2}$ Institute of Molecular Pathogenesis, Friedrich-Loeffler-Institute (FLI), Federal Research Institute for Animal \\ Health, Jena, Germany \\ ${ }^{3}$ Charité Hospital, CCM, Laboratory for Molecular Genetics, Polymicrobial Infections and Bacterial Biofilms, \\ Department of Medicine, Gastroenterology, Universitätsmedizin Berlin, Berlin, Germany \\ Email: ${ }^{*}$ andreas.berk@fli.bund.de
}

Received 25 June 2014; revised 28 July 2014; accepted 9 August 2014

Copyright (C) 2014 by authors and Scientific Research Publishing Inc.

This work is licensed under the Creative Commons Attribution International License (CC BY).

http://creativecommons.org/licenses/by/4.0/

(c) (i) Open Access

\section{Abstract}

A total of 80 piglets $(7.9 \pm 1.0 \mathrm{~kg})$ were used in a feeding experiment with dried oregano. The diets differed in their oregano content: $0 \mathrm{~g}, 2 \mathrm{~g}, 4 \mathrm{~g}$ and $8 \mathrm{~g}$ oregano/ $\mathrm{kg}$ feed, corresponding to $0,23.5$, 46.9 and $93.9 \mathrm{mg}$ carvacrol/kg DM. After the experimental period of 5 weeks, 20 piglets of both extreme feeding groups were slaughtered: 10 animals of the control group and 10 animals of the group that received $8 \mathrm{~g}$ oregano/kg. Ingesta samples of jejunum, caecum and colon were collected and analyzed by FISH and PCR RFLP to compare the diversity of microbiota. The results showed no significant changes in microbiota in response to oregano. The patterns of the PCR-RFLP showed a similarity of $61.8 \%-91.8 \%$ in both feeding groups. In conclusion, an effect of oregano on the intestinal microbiota could not be shown under the methods used.

\section{Keywords}

Piglets, Origanum vulgare L., Fluorescence in Situ Hybridization, Restriction Fragment Length Polymorphism, Intestinal Microorganisms

\footnotetext{
${ }^{*}$ Corresponding author.
}

How to cite this paper: Stelter, K., et al. (2014) The Use of Restriction Fragment Length Polymorphism and Fluorescence in Situ Hybridization to Investigate Microbiota of Piglets after Feeding Oregano. Food and Nutrition Sciences, 5, 1628-1636. http://dx.doi.org/10.4236/fns.2014.517175 


\section{Introduction}

Weaning with the separation of the sow and the new environmental conditions is a very stressful situation for piglets. Especially the change from suckling to solid feed is a major challenge for the pig and is associated with major changes in the microbiota of the gastrointestinal tract (GIT). The GIT represents a dynamic ecosystem which is very complex and consists of micro-aerophilic and anaerobic microbes [1] that are important for nutrient digestion, the support of the mucosal immunity and the development of the gut-associated-lymphoid tissue [2]. Stress during weaning often caused an altered composition of the microbiota in the gut [3] [4]. Piglets with a low diversity of the enteric flora were more susceptible to diarrhea than animals with a high diversity [5]. Konstantinov et al. [1] postulated that a stable and complex microbiota is a prerequisite for healthy bowel function. To support the mucosal immunity and the microbiota in this critical period of life, the Mediterranean herb Origanum vulgare L. with its antimicrobial abilities was focused on [6] [7]. The main components of its essential oil are carvacrol and thymol which were used in several in vitro investigations to evaluate the antimicrobial activity [8]-[10]. For example, in vitro investigations of Michiels et al. [11] with essential oil components of oregano (carvacrol and thymol) showed antimicrobial opportunities in gastric, jejunal and ceacal simulations. The researchers recognized a reducing effect on total anaerobic bacteria in all three types of simulations. In vivo investigations with oregano supplementation to the feed could lead to alterations in microbial counts, for example lactobacilli [12] [13]. Herb supplementations, in general, are suggested to reduce only harmful coliform bacteria in the gut while in-feed antibiotics presumably inhibit also the proliferation of beneficial bacteria like lactobacilli [14]. In previous studies, oregano was commonly administered as extract or essential oil, whereas the aim of the current investigation was to examine the influence of dried oregano plant material on the gut microbiota of weaning piglets.

\section{Material and Methods}

\subsection{Plant Material}

The utilized Origanum vulgare L., belonging to the labiate family, was cultivated and harvested on the experimental plots of the Institute for Plant Cultivation, Schnega, Germany. The aerial parts were harvested by manual cutting after the flowering stage in mid-September 2011. Thereafter, the plant material was dried down to a final moisture content of app. $9 \%$ at $40^{\circ} \mathrm{C}$ in tray driers. Finally, the dried oregano was ground to $4 \mathrm{~mm}$ using a hammer mill (Joachim Kreyenborg \& Co, type 10, Münster-Kinderhaus, Germany). Analysis of the monoterpenes content ensued and was determined on dry matter (DM) basis.

\subsection{Experimental Design}

\subsubsection{Animal Experiment}

The experiment was conducted at the Institute of Animal Nutrition, Federal Research Institute for Animal Health, Braunschweig, Germany in March 2012 according to the European Community regulations concerning the protection of experimental animals and the guidelines of the regional council of Oldenburg, Lower Saxony, Germany.

The present investigations were performed within the frame of a more comprehensive piglet experiment examining the effects of increasing proportions of dried oregano plant material in piglet feed on performance and health. The experiment is described in detail elsewhere [15].

For the investigation 80 male castrated piglets with an average body weight of $7.9 \pm 1.0 \mathrm{~kg}$ were housed in floor pens of the piglet compartment. Piglets were allowed five days of adaptation prior to the onset of the experimental period. On day one of the study all piglets were weighed and allocated to four feeding groups according to their individual weight $(\mathrm{n}=20)$. The allocation into four groups resulted in a number of four animals per box $(n=5)$. The diet without oregano supplementation served as control diet $(\mathrm{CON})$ while the other three diets included $2 \mathrm{~g}$ oregano/kg feed (Group 1), $4 \mathrm{~g}$ oregano/kg feed (Group 2) or $8 \mathrm{~g}$ oregano/kg feed (Group 3), corresponding to calculated dietary carvacrol concentrations of $23.5 \mathrm{mg}, 46.9 \mathrm{mg}$ and $93.9 \mathrm{mg} / \mathrm{kg} \mathrm{DM}$, respectively. The dried and milled oregano was admixed to the basic diet to obtain the desired concentrations. The diets consisted mainly of cereals, soy feedstuff, amino acids, vitamins and minerals to meet the recommendations of the Society of Nutrition Physiology [16]. The compositions of the diets are shown in Table 1. Feed, in mesh form, and water were offered ad libitum during the experimental period of five weeks. For the current experiment, only 20 animals of the extreme feeding groups (CON and $8 \mathrm{~g}$ oregano/kg feed) were focused on. 
Table 1. Composition and characteristics of experimental diets (g/kg).

\begin{tabular}{|c|c|c|}
\hline & \multicolumn{2}{|c|}{ Group } \\
\hline & $\mathrm{CON}$ & ORE \\
\hline \multicolumn{3}{|l|}{ Components } \\
\hline Barley & 339.35 & 331.35 \\
\hline Wheat & 300.00 & 300.00 \\
\hline Maize extruded & 100.00 & 100.00 \\
\hline Soybean meal extracted & 150.00 & 150.00 \\
\hline Soy protein concentrate & 50.00 & 50.00 \\
\hline Soybean oil & 30.00 & 30.00 \\
\hline Mineral and vitamin premix ${ }^{1}$ & 19.00 & 19.00 \\
\hline Amino acids ${ }^{2}$ & 11.50 & 11.50 \\
\hline Phytase & 0.15 & 0.15 \\
\hline Oregano & - & 8.00 \\
\hline \multicolumn{3}{|l|}{ Calculated terpenes (mg/kg DM): } \\
\hline Carvacrol & - & 93.9 \\
\hline Thymol & - & 7.5 \\
\hline y-Terpinen & - & 3.1 \\
\hline$\beta$-Caryophyllen & - & 3.1 \\
\hline p-Cymol & - & 1.4 \\
\hline \multicolumn{3}{|l|}{ Analyzed composition (g/kg DM): } \\
\hline Dry matter & 899 & 896 \\
\hline Crude protein & 213 & 203 \\
\hline Ether extract & 61 & 55 \\
\hline Crude fiber & 34 & 39 \\
\hline Starch & 479 & 486 \\
\hline Sugar & 52 & 51 \\
\hline $\mathrm{ME}[\mathrm{MJ} / \mathrm{kg} \mathrm{DM}]^{3}$ & 15.87 & 15.73 \\
\hline
\end{tabular}

CON, control group; ORE, feeding group with $8 \mathrm{~g}$ oregano $/ \mathrm{kg}$ feed. ${ }^{1}$ Ingredients per kg complete diet: Ca 4.5 g, P 1.4 g, Na 0.9 g, Mg 0.08 g, Fe 75 mg, Cu 15 mg, Mn 40 mg, Zn 50 mg, I $1 \mathrm{mg}$, Se $0.2 \mathrm{mg}$, Co $0.4 \mathrm{mg}$, Vit A $10.000 \mathrm{IU}$, Vit $\mathrm{D}_{3} 1.000 \mathrm{IU}$, Vit E $50 \mathrm{mg}$, Vit $\mathrm{B}_{1} 1 \mathrm{mg}$, Vit $B_{2} 3.1 \mathrm{mg}$, Vit $B_{6} 2.5 \mathrm{mg}$, Vit $B_{12} 20 \mu \mathrm{g}$, Vit $\mathrm{K}_{3} 2 \mathrm{mg}$, Vit C $50 \mathrm{mg}$, Nicotinic acid 12.5 mg, Folic acid $0.5 \mathrm{mg}$, Choline chloride $125 \mathrm{mg}$, Biotin $50 \mu \mathrm{g} .{ }^{2}$ Ingredients per kg complete diet: lysin-HCl 6 g, DL-methionine $3 \mathrm{~g}$, L-threonine $2 \mathrm{~g}$, L-tryptophan $0.5 \mathrm{~g}$. ${ }^{3}$ Calculated on base of digestible (table values of the used compounds) crude nutrients (as analysed) according to the formula of the GfE [17]: ME [MJ] $=0.0205 \cdot \mathrm{DCP}[\mathrm{g}]+0.0398 \cdot \mathrm{DCL}[\mathrm{g}]+0.0173$ - St [g] + 0.0160 - Su [g] + 0.0147 • (DOM - DCP - DCL - St - Su $)$ [g]; where: OM = organic matter, $\mathrm{CP}=$ crude protein, $\mathrm{CL}=$ crude fat, $\mathrm{St}=$ starch, $\mathrm{Su}=$ sugar and $\mathrm{D}=$ digestible.

\subsubsection{Collection Procedures}

After terminating the feeding experiment of five weeks, 10 piglets of the control group and 10 animals of Group 3 (8 g oregano $/ \mathrm{kg}$ ) with an average body weight of $19.9 \pm 2.7 \mathrm{~kg}$ were slaughtered by electrical stunning followed by exsanguination to evaluate intestinal microbiota. The piglets were allowed feed intake prior to slaughter to obtain well-filled intestines. The gastrointestinal tract (GIT) was removed carefully to avoid digesta mixing and samples taken from jejunum, cecum and colon. For analysis the entire ingesta of the jejunum was collected by carefully squeezing and mixed thoroughly while samples of cecum and colon were collected at a defined location. All samples for PCR-RFLP analysis were frozen immediately after collection at $-20^{\circ} \mathrm{C}$, while samples for FISH were fixed in Carnoy's solution [18] until analysis.

\subsection{Analyses}

\subsubsection{Oregano and Feed}

Representative samples of each diet were collected and analyzed for dry matter, crude ash, crude protein (N 
$\times$ 6.25), ether extract ( $\mathrm{HCl}$ digestion), crude fiber, sugar (Luff-Schoorl) and starch according to the methods of the Association of German Agricultural Analysis and Research Centres [19]. Prior to mixing the feed with oregano, the monoterpenes content was examined. For this, $50 \mathrm{mg}$ dried plant material spiked with tetradecane as internal standard was extracted with $1 \mathrm{ml} n$-hexane in the ultrasonic bath $\left(1\right.$ hour, $\left.15^{\circ} \mathrm{C}\right)$. After centrifugation (10 minutes at about 10,000 $\times$ g) and filtration the extract was subjected to gas chromatography (Perkin Elmer Auto System, equipped with flame ionization detector). The extract was chromatographed on a DB1-like Zebron ZB-AAA capillary column $(10 \mathrm{~m}, 0.25 \mathrm{~mm})$. The injection volume was set to $1.5 \mu \mathrm{l}$ and the flow rate to $450 \mathrm{ml} \mathrm{He} /$ minute. The oven temperature program was as follows: 2 minutes at $70^{\circ} \mathrm{C}, 140^{\circ} \mathrm{C}$ at $8{ }^{\circ} \mathrm{C} /$ minute followed by $220^{\circ} \mathrm{C}$ at $20^{\circ} \mathrm{C} /$ minute and held for 2 minute at $220^{\circ} \mathrm{C}$. Analysis of the monoterpenes revealed the following composition: p-cymene $(0.18 \mathrm{~g} / \mathrm{kg}), \beta$-caryophyllene $(0.38 \mathrm{~g} / \mathrm{kg}), \gamma$-terpinene (0.39 g/kg), thymol (0.94 g/kg), carvacrol $(11.7 \mathrm{~g} / \mathrm{kg})$.

\subsubsection{PCR-RFLP Analysis}

For DNA analysis, samples of about $1 \mathrm{~g}$ of ingesta of the proximal colon were kept in sterile Falcon tubes and frozen immediately $\left(-20^{\circ} \mathrm{C}\right)$ until PCR-RFLP analysis. Prior to the analysis DNA of the ingesta samples was extracted with the commercial QIAamp ${ }^{\circledR}$ DNA Stool Mini Kit (QIAGEN ${ }^{\circledR}$, Hilden, Germany) as recommended by the manufacturer. The total bacteria of the ingesta was analyzed according to Castillo et al. [13]. A 580-bp fragment of 16S rRNA gene was amplified from DNA extracts by PCR. For these purpose primers specific to conserved sequences flanking variable regions V3, V4 and V5 were utilized: 5'-CTACGGGAGGCAGCAGT-3' (forward) and 5'-CCGTCWATTCMTTTGAGTTT-3' (reverse). The DNA was amplified using a FlexCycler (Analytik Jena AG, Jena, Germany) with the following conditions: One denaturation step of 4 minutes at $94^{\circ} \mathrm{C}$, followed by 35 cycles of denaturation at $94^{\circ} \mathrm{C}$ ( 1 minute), annealing at $45^{\circ} \mathrm{C}$ ( 1 minute) associated with an increasing temperature of $0.1^{\circ} \mathrm{C}$ per cycle, extension at $72^{\circ} \mathrm{C}$ (1 minute 15 seconds) and a final extension at $72^{\circ} \mathrm{C}$ (15 minutes). After amplification the PCR products were visualized with agarose gel electrophoresis. The next step was the enzymatic restriction with three independent restriction enzymes (RsaI, HpaII and HhaI (New England Biolabs GmbH, Frankfurt/M, Germany). The digestion was carried out with the appropriate restriction buffer at $37^{\circ} \mathrm{C}$ for 3 hours as recommended by the manufacturer. Using a $2 \%$ high-resolution agarose gel, the fragments were separated. Bands between 100 and 580 bp length were used to generate restriction profiles for each piglet. For pairwise comparisons of restriction profiles and construction of dendrograms, similarity matrices were generated with Hierarchical Clustering Explorer 3.0 [20] using Manhattan distance.

\subsubsection{Fluorescence in Situ Hybridisation (FISH)}

Ingesta samples of about $1 \mathrm{ml}$ from jejunum, cecum and colon for fluorescence in situ hybridization (FISH) were immediately fixed in Carnoy's solution [18] for at least 12 hours. Similar conditions were used for gram positive and gram negative bacteria. The ingesta samples were assessed with group specific 16S rRNAgenetargeted oligonucleotide probes (Table 2, [21]-[26]). FISH method was performed according to Swidsinski [27]. The soft chyme sediment from the fixed samples was directly pipetted on a slide $(50 \mu \mathrm{l})$ and then dried at $50^{\circ} \mathrm{C}$ for 30 minutes. Next, the hybridization step followed. The utilized oligonucleotide probes were synthesized with the reactive fluorescent dye carbocyanite 3 (Сy3) (Bifidobacterium group, Faecalibacterium prausnitzii group) or Cy5 (Enterobacteriaceae group, Bacteroides group, MWG Biotech, Ebersberg, Germany) at the 5'-end. Detecting all relevant bacteria the universal probe Eub338 was used as well as the nonsense probe Non338 to test nonspecific binding of oligonucleotide probes. Hybridization temperature was $50^{\circ} \mathrm{C}$ and formamide concentration was $1 \%$. The quantification of the fecal bacteria was performed under a Nikon e600 fluorescence microscope (Nikon, Tokyo, Japan). The documentation of the bacteria was conducted using a Nikon DXM 1200F color camera and software (Nikon, Tokyo, Japan).

\subsection{Statistical Analysis}

The results of the FISH analysis were tested with a multifactorial ANOVA using the GLM procedure of the SAS-software (SAS Enterprise Guide 4.3). The intestinal segment and the feeding group were defined as fixed effects. Values presented in the paper below are shown as mean \pm standard deviation (SD).

Analysis of RFLP pattern was performed with Bionumerics (version 6.6, applied Maths, Belgium) and Hierarchical Clustering Explorer 3.0 (Human-Computer Interaction Lab, University of Maryland). 
Table 2. Sequences of oligonucleotide probes.

\begin{tabular}{ccccc}
\hline Probe & Probe sequence $\left(\mathbf{5}^{\prime} \rightarrow \mathbf{3}^{\prime}\right.$ ) & Targeted species & $\begin{array}{c}\text { Fluorescent } \\
\text { dye }\end{array}$ & Reference \\
\hline Bac303 & CCA ATG TGG GGG ACC TT & $\begin{array}{c}\text { most Bacteroidaceae and Prevotellaceae, } \\
\text { some Porphyromonadacea }\end{array}$ & Cy5 & Manz et al. [21] \\
Bif164 & CAT CCG GCA TTA CCA CCC & Bifidobacterium spp. & Cy3 & Langendijk et al. [22] \\
Fprau645 & CCT CTG CAC TAC TCA AGA AAA AC & Fusobacterium prausnitzii and relatives & Cy3 & Suau et al. [23] \\
Ebac1790 & CGT GTT TGC ACA GTG CTG & Enterobacteriaceae & Cy5 & Bohnert et al. [24] \\
Eub338 & GCT GCC TCC CGT AGG AGT & most Bacteria & FITC & Amann et al. [25] \\
NonEub338 & ACT CCT ACG GGA GGC AGC & control probe & Wallner et al. [26] \\
\hline
\end{tabular}

\section{Results}

In general, all animals accepted the oregano supplemented feed and there were no acute pathologies in any of the piglets, all animals appeared to be in good health. An effect on the performance data has failed during the whole experimental period. The piglets had an average daily gain of $473 \pm 80 \mathrm{~g} / \mathrm{d}$ and a daily feed intake of 796 $\pm 79 \mathrm{~g} /$ animal during the whole experimental time [15].

\subsection{Diet Composition}

The analytical results of the chemical compositions of the various experimental diets are shown in Table 1. The values were attained according to the recommendations of the Society of Nutrition Physiology [16].

\subsection{Distribution and Morphology of Bacteria Analyzed by FISH}

The microorganisms in the investigated intestinal segments were mainly concentrated in the caecum and colon independent of oregano supplementation. Small amounts of microorganisms were counted in the jejunum in contrast to caecum and colon, except for Bifidobacteria (Bif) which were the major genus in this segment. In Figure 1 the distribution of the microorganisms is summarized. It was notable that the bacteria have populated the majority of the caecum and colon. While higher counts of enterobacteria were detected in colon, more amounts of Bifidobacteria colonized the caecum. The statistical results of the FISH analysis are not documented in writing, because there are, partially, an insufficient number of bacterial counts in the different parts of the intestine and due to the high individual variations and the ensued high standard deviation, no significant differences are recognized (Figure 1). Additionally, the results showed no influence on the microorganisms of the examined intestinal segments in response to the oregano supplementation.

Morphology of the microorganisms in the jejunum was inconspicuously in the control group and oregano supplemented animals of Group 3. Noteworthy in the caecum was the formation of isles of Fpr in oregano and control group. Further, there were small and chain coccus-type species as well as rod bacteria. Similarly to the morphology of the Fpr the Bif were also accumulated in isle formation independent of oregano supplementation. The morphology of the microorganisms of the colon showed no difference in control animals and oregano group.

\subsection{Effect of Oregano on Microbial Composition as Estimated by RFLP}

The used three enzymatic restrictions resulted in a specific number of bands to express the bacterial richness in the collected ingesta of the three different intestinal parts. The analysis of the HhaI restriction profiles included the presence or absence of 16, for HpaII of 14 and for RsaI of 12 clearly differentiable bands. By combining the results for all three enzymes for each piglet was an individual pattern created characterized by 17 through 29 bands per profile. The cluster analysis of patterns by the example of three animals of each group is shown in Figure 2.

The patterns clustered with $61.8 \%$ to $91.8 \%$ similarity between piglets from control group and oregano fed animals and up to $97.2 \%$ similarity between piglets within one of the both groups. Thereby no clear assignment of the patterns to the groups of the piglets according to their feeding background was possible. 


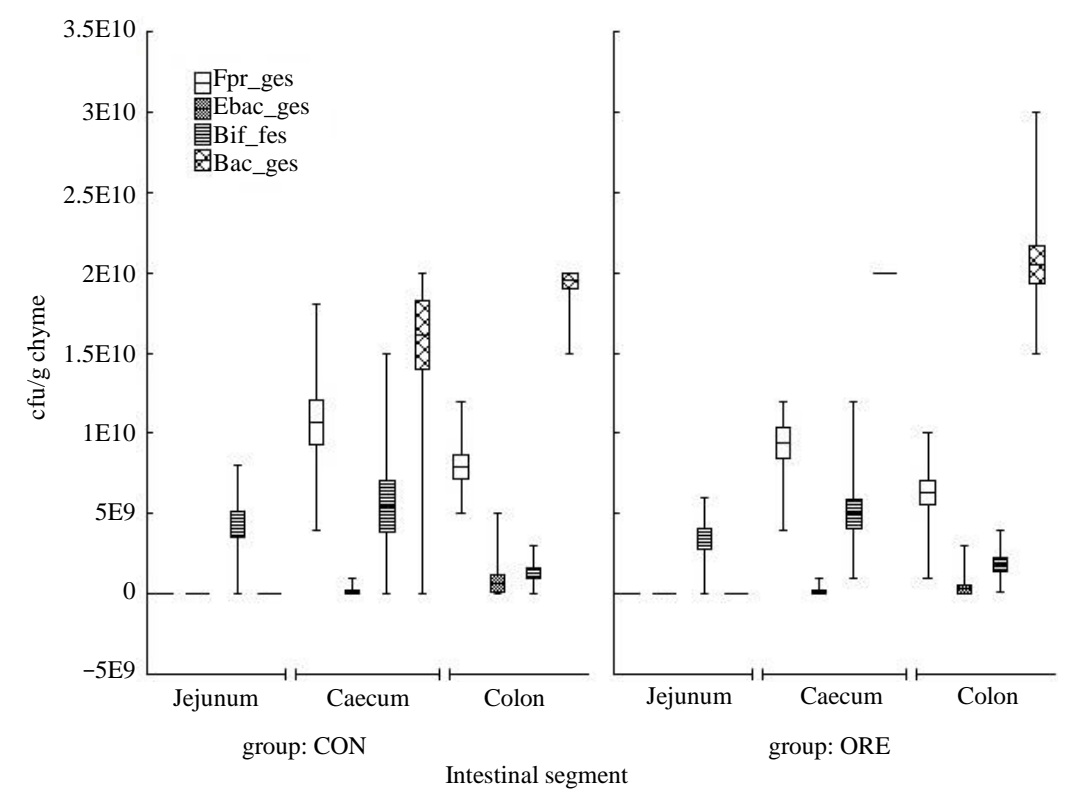

Figure 1. Microbiological biodiversity in the intestine as measured by FISH. Comparison of the microflora of the chyme collected from different intestinal segments of control (CON) and oregano group (ORE, $8 \mathrm{~g}$ oregano $/ \mathrm{kg}$ diet). Shown are mean $\pm \mathrm{SD}$ (box) and minimum-maximum (whisker).

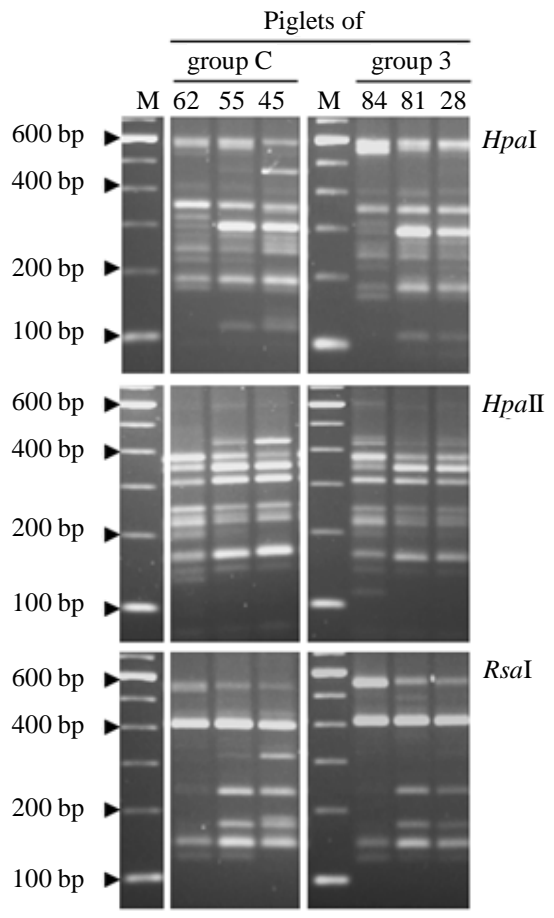

(a)

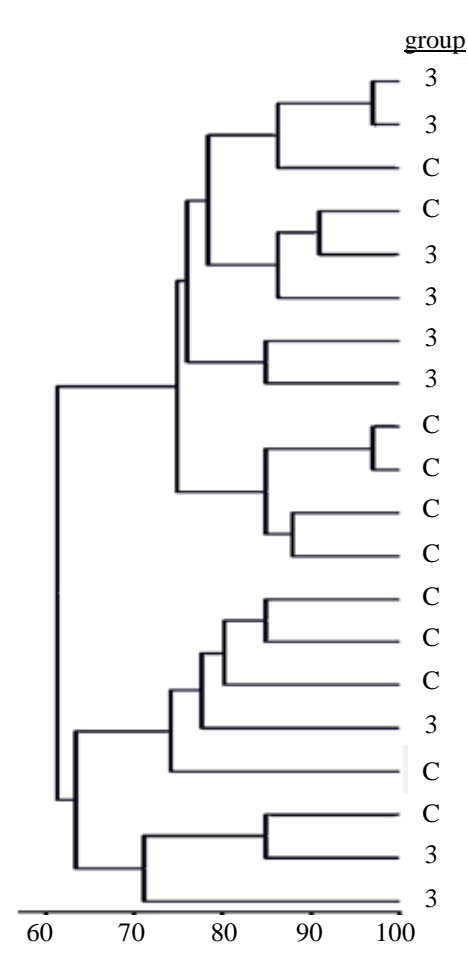

(b)

Figure 2. Microbiological biodiversity in the proximal colon measured by PCRRFLP. (a) Agarose gels after ethidium bromide staining with representative restriction profiles of 16S rRNS fragments with the three enzymes used (shown by the example of 3 animals of each group); (b) The dendrogram represents the percentage of similarity of the 16S rRNA fragment restriction profiles for the oregano fed animals (Group 3, fed with $8 \mathrm{~g} / \mathrm{kg}$ oregano) and the control animals (Group C, without oregano) (UPGMA, Manhattan distance). 


\section{Discussion}

The present experiment is aimed at examining the effect of dried oregano supplementation on the microorganisms of jejunum, caecum and colon as representative segments and supposed action sites of oregano within the intestinal tract. Therefore, piglets were slaughtered and ingesta of the mentioned intestinal parts was collected and analyzed with regard to the spatial organization of the gut microbiota.

The microbial biodiversity in the gastrointestinal tract (GIT) of the piglets is a very complex system of several anaerobic and micro-aerophilic microbes. Several researchers have been working on the microbial communities in the GIT [1] [28]. Most of the microbiota located in the intestine belongs to the genera Streptococcus, Lactobacillus, Fusobacterium, and Peptostreptococcus. Additionally, there is the Bacteroides and Prevotella group which are the gram-negative organisms [1].

In the present study the genera Faecalibacterium, Enterobacteria, Bifidobacteria, Bacteroides and Prevotella group in piglet's ingesta of jejunum, caecum and colon were examined by FISH analysis and PCR-RFLP.

No significant effects of oregano supplementation on microbial composition of the control group compared to oregano fed animals were recognized with the methods used in the current study. Accordingly to investigations of Muhl and Liebert [29] in which a phytogenic feed additive (PFA) with carvacrol and thymol was utilized no significant influences by dietary treatment were achieved. In contrast to the current investigation, the mentioned researchers examined the populations of total culturable anaerobic bacteria while in the present study the detection of the microbiota based on molecular biology techniques. Manzanilla et al. [12] also used the traditional cultivation technique but recognized a significant increase of lactobacilli and a tended decrease of enterobacteria under the stimulation of 150 or $300 \mathrm{mg}$ PFA/kg consisting of $5 \%$ carvacrol, $3 \%$ cinnamaldehyd and $2 \%$ capsicum oleoresin. As a consequence of the supplementation of the plant extract mixture the ratio between lactobacilli and enterobacteria showed a significant increase. This ratio was suggested as a parameter to allow evaluating the intestinal health. The enterobacteria in the current study were not influenced by dried oregano supplementation, therefore it is possible that the effects mentioned by Manzanilla et al. [12] were due to the use of a plant extracts or the mixture of the three plant materials. Castillo et al. [13] also used a PFA with the same concentration of plant extracts like the working group of Manzanilla et al. [12] did. In their investigation no influence of the PFA on the enterobacteria in jejunum and caecum was recognized, which is in accordance with the current study.

Carvacrol and thymol as main components of the essential oil of oregano did not influence any bacterial group when administered as pure compound $(2000 \mathrm{mg} / \mathrm{kg}$ ) in different formulation types (soybean oil, inert carrier and microencapsulation) in the investigation of Michiels et al. [30]. They suggested that the high dry matter content of the gastric ingesta and the fast absorption in the small intestine were the reason for the non-existent influence on the bacterial load. Hence, the question arises, whether a higher amount of dried oregano plant material and a more concentrated carvacrol and thymol content resulted in a slower absorption rate in the small intestine followed by an increased availability of the active substances in the gut.

The PCR-RFLP analysis of 16S rRNS genes in DNA extracts of the ingesta was chosen to mirror the whole bacterial diversity. In contrast to Castillo et al. [13] [28] we were not able to detect specific ecological changes in feeding groups fed with or without oregano. Castillo et al. [13] pointed out that different treatments leads to different clusters. The differences were the result of the increasing biodiversity in the microbial ecosystem due to the use of feed additives. Investigations in humans showed a high similarity in intestinal microbiota in twins [31]. Therefore it is noteworthy that no information about the litter, the dam or the sire was available in the current investigation which could also be possible factors for non-detectable ecological changes by oregano supplementation.

\section{Conclusion}

The supplementation of dried oregano did not influence the microbiota of the intestinal tract of piglets. Therefore, the question arises whether a higher amount of dried oregano influences the microbiota and if other genera like Lactobacillus were more affected by oregano than the analyzed ones. The PCR-RFLP pattern showed no influences of oregano supplementation in the piglets. Maybe there is an influence of the parentage on the microbiota, which could be recognized in further investigations, especially with siblings by using molecular biology techniques. 


\section{Acknowledgements}

The authors would like to thank the co-workers of the Institute of Animal Nutrition of the Friedrich-LoefflerInstitute (FLI) in Braunschweig Germany in performing experiment and analyses. And we acknowledge the excellent technical assistance from S. Schares (FLI, Riems).

\section{References}

[1] Konstantinov, S.R., Favier, C.F., Zhu, W.Y., Williams, B.A., Kluss, J., Souffrant, W.B., de Vos, W.M., Akkermans, A.D.L. and Smidt, H. (2004) Microbial Diversity Studies of the Porcine Gastrointestinal Ecosystem during Weaning Transition. Animal Research, 53, 317-324. http://dx.doi.org/10.1051/animres:2004019

[2] Bauer, E., Williams, B.A., Smidt, H., Verstegen, M.W. and Mosenthin, R. (2006) Influence of the Gastrointestinal Microbiota on Development of the Immune System in Young Animals. Current Issues in Intestinal Microbiology, 7, 3551.

[3] Wallgren, P. and Melin, L. (2001) Weaning Systems in Relation to Disease. CABI Publishing, Wallingford, 309-316.

[4] Lallès, J.-P., Bosi, P., Smidt, H. and Stokes, C.R. (2007) Weaning-A Challenge to Gut Physiologists. Livestock Science, 108, 82-93. http://dx.doi.org/10.1016/j.livsci.2007.01.091

[5] Kühn, I., Katouli, M., Lund, A., Wallgren, P. and Mollby, R. (1993) Phenotypic Diversity and Stability of the Intestinal Coliform Flora in Piglets during the First 3 Months of Age. Microbial Ecology in Health and Disease, 6, 101-107. http://dx.doi.org/10.3109/08910609309141313

[6] Şahin, F., Güllüce, M., Daferera, D., Sökmen, A., Sökmen, M., Polissiou, M., Agar, G. and Özer, H. (2004) Biological Activities of the Essential Oils and Methanol Extract of Origanum Vulgare ssp. Vulgare in the Eastern Anatolia Region of Turkey. Food Control, 15, 549-557. http://dx.doi.org/10.1016/j.foodcont.2003.08.009

[7] Burt, S. (2004) Essential Oils: Their Antibacterial Properties and Potential Applications in Foods-A Review. International Journal of Food Microbiology, 94, 223-253. http://dx.doi.org/10.1016/j.ijfoodmicro.2004.03.022

[8] Henn, J.D., Bertol, T.M., de Moura, N.F., Coldebella, A., de Brum, P.A.R. and Casagrande, M. (2010) Oregano Essential Oil as Food Additive for Piglets: Antimicrobial and Antioxidant Potential. Revista Brasileira De Zootecnia-Brazilian Journal of Animal Science, 39, 1761-1767. http://dx.doi.org/10.1590/S1516-35982010000800019

[9] Mathlouthi, N., Bouzaienne, T., Oueslati, I., Recoquillay, F., Hamdi, M., Urdaci, M. and Bergaoui, R. (2012) Use of Rosemary, Oregano, and a Commercial Blend of Essential Oils in Broiler Chickens: In Vitro Antimicrobial Activities and Effects on Growth Performance. Journal of Animal Science, 90, 813-823. http://dx.doi.org/10.2527/jas.2010-3646

[10] Çetin, B., Çakmakçi, S. and Çakmakçi, R. (2011) The Investigation of Antimicrobial Activity of Thyme and Oregano Essential Oils. Turkish Journal of Agriculture Forestry, 35, 145-154.

[11] Michiels, J., Missotten, J.A.M., Fremaut, D., De Smet, S. and Dierick, N.A. (2009) In Vitro Characterisation of the Antimicrobial Activity of Selected Essential Oil Components and Binary Combinations against the Pig Gut Flora. Animal Feed Science and Technology, 151, 111-127. http://dx.doi.org/10.1016/j.anifeedsci.2009.01.004

[12] Manzanilla, E.G., Perez, J.F., Martin, M., Kamel, C., Baucells, F. and Gasa, J. (2004) Effect of Plant Extracts and Formic Acid on the Intestinal Equilibrium of Early-Weaned Pigs. Journal of Animal Science, 82, 3210-3218.

[13] Castillo, M., Martín-Orúe, S.M., Roca, M., Manzanilla, E.G., Badiola, I., Perez, J.F. and Gasa, J. (2006) The Response of Gastrointestinal Microbiota to Avilamycin, Butyrate, and Plant Extracts in Early-Weaned Pigs. Journal of Animal Science, 84, 2725-2734. http://dx.doi.org/10.2527/jas.2004-556

[14] Namkung, H., Gong, M., Li J., Yu, H., Cottrill, M. and de Lange, C.F.M. (2004) Impact of Feeding Blends of Organic Acids and Herbal Extracts on Growth Performance, Gut Microbiota and Digestive Function in Newly Weaned Pigs. Canadian Journal of Animal Science, 84, 697-704. http://dx.doi.org/10.4141/A04-005

[15] Stelter, K., Frahm, J., Paulsen, J., Berk, A., Kleinwächter, M., Selmar, D. and Dänicke, S. (2013) Effects of Oregano on Performance and Immunmodulating Factors in Weaned Piglets. Archives of Animal Nutrition, 67, 461-476. http://dx.doi.org/10.1080/1745039X.2013.858897

[16] GfE, Society of Nutrition Physiology (2006) Recommendations for the Supply of Energy and Nutrients to Pigs Energy and Nutrients Requirements for Livestock. Committee for Requirement Standards of the Society of Nutrition Physiology, Ed. DLG-Verlags GmbH. Frankfurt am Main, Germany.

[17] GfE (2008) Society of Nutrition Physiology, Recommendations for the Supply of Energy and Nutrients to Pigs. DLGVerlags GmbH, Frankfurt am Main, Germany.

[18] Matsuo, K., Ota, H., Akamatsu, T., Sugiyama, A. and Katsuyama, T. (1997) Histochemistry of the Surface Mucous Gel Layer of the Human Colon. Gut, 40, 782-789. http://dx.doi.org/10.1136/gut.40.6.782 
[19] Naumann, C. and Bassler, R. (1993) Die chemische Untersuchung von Futtermitteln. VDLUFA-Verlag, Darmstadt, Germany.

[20] Seo, J. and Shneiderman, B. (2003) Understanding Hierarchical Clustering Results by Interactive Exploration of Dendrograms: A Case Study with Genomic Microarray Data. Department of Computer Science \& Human-Computer Interaction Laboratory, Institute for Advanced Computer Studies University of Maryland, USA.

[21] Manz, W., Amann, R., Ludwig, W., Vancanneyt, M. and Schleifer, K.-H. (1996) Application of a Suite of 16S rRNASpecific Oligonucleotide Probes Designed to Investigate Bacteria of the Phylum Cytophaga-Flavobacter-Bacteroides in the Natural Environment. Microbiology, 142, 1097-1106. http://dx.doi.org/10.1099/13500872-142-5-1097

[22] Langendijk, P.S., Schut, F., Jansen, G.J., Raangs, G.C., Kamphuis, G.R., Wilkinson, M.H. and Welling, G.W. (1995) Quantitative Fluorescence in Situ Hybridization of Bifidobacterium spp. with Genus-Specific 16S rRNA-Targeted Probes and Its Application in Fecal Samples. Applied and Environmental Microbiology, 61, 3069-3075.

[23] Suau, A., Rochet, V., Sghir, A., Gramet, G., Brewaeys, S., Sutren, M., Rigottier-Gois, L. and Doré, J. (2001) Fusobacterium prausnitzii and Related Species Represent a Dominant Group within the Human Fecal Flora. Systematic and Applied Microbiology, 24, 139-145. http://dx.doi.org/10.1078/0723-2020-00015

[24] Bohnert, J., Hubner, B. and Botzenhart, K. (2000) Rapid Identification of Enterobacteriaceae Using a Novel 23S rRNA-Targeted Oligonucleotide Probe. International Journal of Hygiene and Environmental Health, 203, 77-82. http://dx.doi.org/10.1078/S1438-4639(04)70011-5

[25] Amann, R.I., Binder, B.J., Olson, R.J., Chisholm, S.W., Devereux, R. and Stahl, D.A. (1990) Combination of 16S rRNA-Targeted Oligonucleotide Probes with Flow Cytometry for Analyzing Mixed Microbial Populations. Applied and Environmental Microbiology, 56, 1919-1925.

[26] Wallner, G., Amann, R. and Beisker, W. (1993) Optimizing Fluorescent in Situ Hybridization with rRNA-Targeted Oligonucleotide Probes for Flow Cytometric Identification of Microorganisms. Cytometry, 14, 136-143. http://dx.doi.org/10.1002/cyto.990140205

[27] Swidsinski, A. (2011) Fish of Human Clinical Samples. http://www.charite.de/arbmkl/zusatzdataien/fishmethode/fishmethode.htm

[28] Castillo, M., Skene, G., Roca, M., Anguita, M., Badiola, I., Duncan, S.H., Flint, H.J. and Martín-Orúe, S.M. (2007) Application of 16S rRNA Gene-Targetted Fluorescence in Situ Hybridization and Restriction Fragment Length Polymorphism to Study Porcine Microbiota along the Gastrointestinal Tract in Response to Different Sources of Dietary Fibre. FEMS Microbiology Ecology, 59, 138-146. http://dx.doi.org/10.1111/j.1574-6941.2006.00204.x

[29] Muhl, A. and Liebert, F. (2007) Growth and Parameters of Microflora in Intestinal and Faecal Samples of Piglets Due to Application of a Phytogenic Feed Additive. Journal of Animal Physiology and Animal Nutrition, 91, 411-418. http://dx.doi.org/10.1111/j.1439-0396.2006.00668.x

[30] Michiels, J., Missotten, J., Van Hoorick, A., Ovyn, A., Fremaut, D., De Smet, S. and Dierick, N. (2010) Effects of Dose and Formulation of Carvacrol and Thymol on Bacteria and Some Functional Traits of the Gut in Piglets after Weaning. Archives of Animal Nutrition, 64, 136-154. http://dx.doi.org/10.1080/17450390903499915

[31] Palmer, C., Bik, E.M., DiGiulio, D.B., Relman, D.A. and Brown, P.O. (2007) Development of the Human Infant Intestinal Microbiota. PLoS Biology, 5, e177. http://dx.doi.org/10.1371/journal.pbio.0050177 
Scientific Research Publishing (SCIRP) is one of the largest Open Access journal publishers. It is currently publishing more than 200 open access, online, peer-reviewed journals covering a wide range of academic disciplines. SCIRP serves the worldwide academic communities and contributes to the progress and application of science with its publication.

Other selected journals from SCIRP are listed as below. Submit your manuscript to us via either submit@scirp.org or Online Submission Portal.
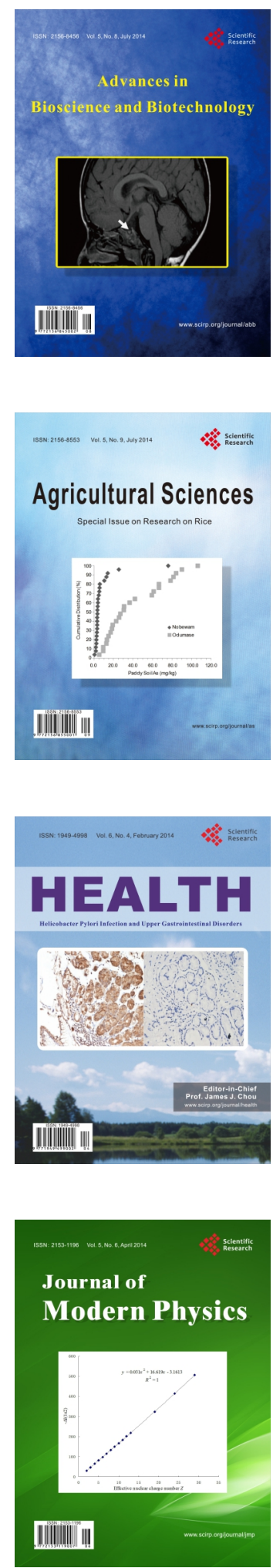
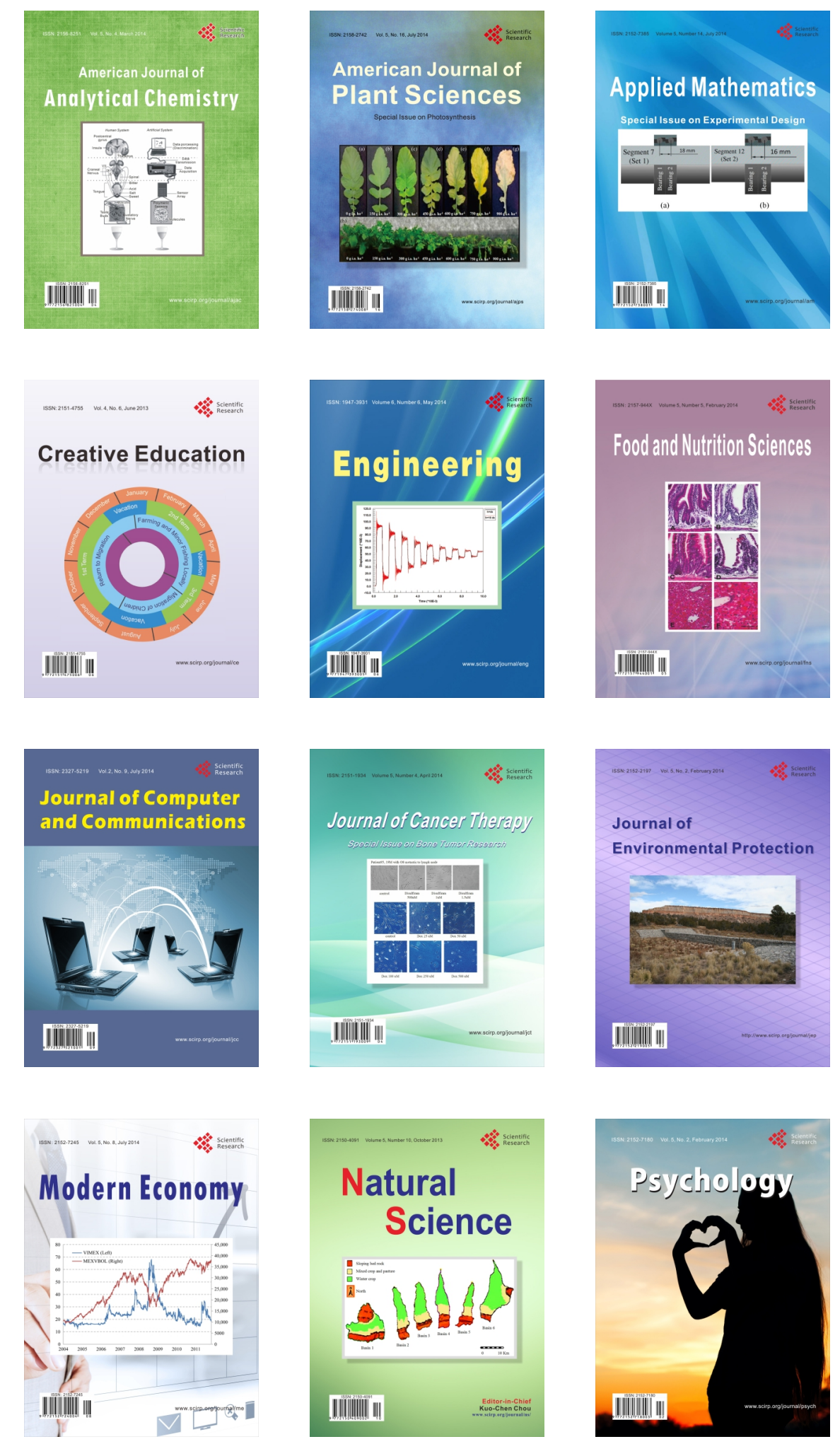